\title{
Then And Now: Kom Awshim in May 1983 and May 1997
}

\section{G. Roche}

Lot 44, Taman Wong Wo Lo, Phase 1, Jalan Tun Mustapha, 87008 W.P. Labuan, MALAYSIA

(email: cgroche172@hotmail.com)

Kom Awshim, the northern extension of the Fayum, has been a noted and productive collecting place for aculeates since the golden age of Egyptian hymenopterology in the 1930's. The Mochi's, father and son, collected there then as did Alfieri and Priesner, who continued there after the war. Krombein and Pulawski followed them in the 1960's, as did Guichard in the 1970 's. I was able to join this famous gathering, collecting extensively there in the 1980's and early 1990's. It has produced a phenomenal number of species, many of them new records for Egypt: Tachysphex crocodilus Pulawski was described from specimens taken there by Krombein, and paratypes of a number of new species described by Pulawski were taken by him there.

The best collecting site by far was the edge of the desert immediately before the olive orchard on the right of the road as one approaches Kom Awshim from Cairo. Olive trees themselves are not attractive to aculeates, but luckily this orchard was not kept as clean as many I have had a look at. There were a lot of Zygophyllum plants and other natural vegetation between the olive trees and at the edge, before the desert there was a fine group of mature Tamarix bushes. Patrolling up and down there would produce 50-100 specimens of anywhere between 25 and 50 species in a morning.

Even before I left Egypt in October 1992, there were ominous signs. The olive plantation was being extended, the Tamarix and other natural plants were being cleaned out. On 1 May 1997 I returned for a collecting trip to the Fayum. Our first stop was in Kom Awshim to which I was eagerly looking forward. To my very great regret olives now prevail exclusively for several hundred metres along the road where before there was desert and, of course, it all is horribly "clean". We did not stop there and went up a track towards the back of the farming area and then on to the edge of the swampy ground. During my 1982-92 days this area was never of much use, but always worth a visit as some species turned up there which were not to be found in the "great" area.

Checking my notes, I find I visited Kom Awshim on 8 May 1983. I took on that occasion 33 sphecid wasps of 14 species and 35 aculeates of other families belonging to 16 species. That compares with the 1997 haul of 10 specimens in total of 8 species. The appendix gives the list of the two day's collecting, so far as they have been determined so far.

Whilst I like olives very much, I cannot help wishing that they were being grown elsewhere.

\section{APPENDIX}

\section{Species taken 8 May 1983:}

Sphecidae: Ammophila erminea Kohl $-1 \delta^{\lambda}$

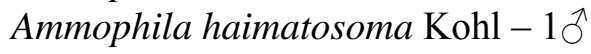

Diodontus friesei Kohl - 1 ㅇ

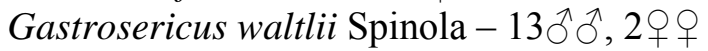

Tachysphex fulvicornis Turner - $1 \hat{\jmath}$

Tachysphex helveticus aegyptiacus Morice $-10^{\lambda}$

?Tachysphex palopterus - $5 \hat{\jmath} \widehat{\jmath}$ (det. not 100\%)

Parapiagetia mongolica (F. Morawitz) $-1 \sigma^{\lambda}$ 
Prosopigastra minima de Beaumont - $2 \hat{\jmath}$

Solierella dispar Pulawski - $1 \widehat{\jmath}$

Miscophus mimeticus Honoré - $1 \delta$

Harpactus laevis aegyptiacus (Schulz) - 19

Hoplisoides ferrugineus (Spinola) $-10^{\lambda}$

Philanthus coarctatus Spinola - 10

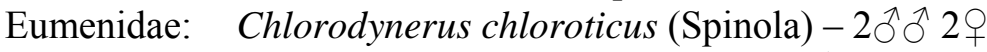

Cyrtolabulus exiguus (Saussure) $-1{ }^{\widehat{ }}$

Eustenancistrocerus inconstans (Saussure) - 1

Pompilidae: Evagetes aegyptiacus Priesner $-1 \hat{0}$

Mutillidae: Dasylabris maura arenaria $-1 \hat{\sigma}$

Scoliidae: Scolia sp. $-2 \hat{\jmath}$

Chrysididae: Chrysis viridissima Klug $-1 \hat{0}$

Chrysis sp. - 1

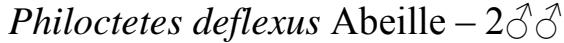

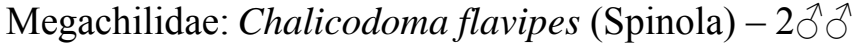

Icteranthidium cinctum (Klug) -1 우

Halictidae: Halictus sp. - 1

Halictus sp. -1 우

Nomioides sp. $-5 \hat{\jmath}$

Nomioides sp. $-1 \hat{\jmath}$

Colletidae: Hylaeus sp. -1 ㅇ

Species taken 1 May 1997:

Sphecidae: Tachysphex schmiedeknechti Kohl 10

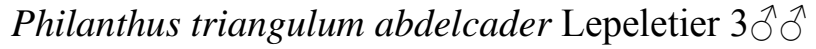

Eumenidae: Eustenancistrocerus inconstans (Saussure) -1 우

Tiphiidae: 1 ก not identified

Megachilidae: 1 specimen each of 2 species not identified

Halictidae: 1 specimen not identified

Colletidae: Hylaeus - 1 specimen not identified 